\title{
Egypten: Når hæren har magten
}

\section{Immanuel Wallerstein}

\section{Det egyptiske højre har vundet, det egyptiske ven- stre har tabt og det Muslimske Broderskab vil gå under jorden, hvorfra det kan komme styrket til- bage. USA og Europa er blevet irrelevante}

Det er næsten altid dårligt nyt, når militæret er ved magten.

I Egypten har hæren imidlertid været den afgørende magt siden 1952. Den nylige afsættelse af præsident Mohamed Morsi var dog ikke et statskup, for man kan ikke begå statskup imod sig selv. Det som skete var slet og ret, at hæren ændrede den måde, som den styrer Egypten. I en kort periode havde hæren tilladt det Muslimske Broderskab at træffe nogle begrænsede beslutninger på statsligt niveau. Men da hæren begyndte at føle, at Morsi-regeringens handlinger kunne føre til en betydelig forøget magt for det Muslimske Broderskab på bekostning af den egyptiske hær, besluttede general Abdel Fattah el-Sisi, at nok var nok. Derfor handlede han brutalt for igen at øge hærens magt i landets dag til dag politik.
Hære ved magten er generelt nationalistiske og meget autoritære, og de tenderer også til at være meget konservative kræfter, når det gælder den globale økonomi. De ledende officerer tillader ikke kun hæren at have en meget direkte rolle i den økonomiske aktivitet, men de har også tendens til at bruge deres militærmagt som en vej til personlig berigelse. Det har afgjort været tilfældet, lige siden den egyptiske hær opnåede direkte magt i 1952 - eller skal vi sige i det mindste siden 1952.

Er det muligt, at hære kan spille en progressiv rolle i national og international politik? Ja, afgjort. Undertiden kan hærens nationalisme få den til at føre en anti-imperialistisk kurs i geopolitik og spille en populistisk rolle ved at støtte underklassens krav og behov. Det var tilfældet med Gamal Abdel Nasser i 
starten. Men progressiv populisme er unaturlig for hære, der finder det vanskeligt at engagere sig i de forhandlingsprocesser, som indenrigspolitikken nødvendigvis kræver. Og progressiv populisme fører til villighed til at påtvinge hærens synspunkter på nabolande, hvorved de underminerer præcis det, som har været progressivt i deres geopolitiske holdninger. Det gjaldt for Nasser, som det også gjaldt for Napoleon.

\section{Før Tahrir Pladsen}

Det særligt interessante ved den egyptiske hærs nedkæmpelse af det Muslimske Broderskab er de reaktioner, som det udløste internt og i omverdenen. Husk på at før den oprindelige opstand imod Hosni $\mathrm{Mu}-$ barak begyndte på Tahrir Pladsen i 2011, var det lykkedes det Muslimske Broderskab at opnå en begrænset rolle i landets politiske liv (en lille minoritet af pladserne i parlamentet og nogle begrænsninger af undertrykkelsen af Broderskabet) gennem en uskreven aftale med Mubarak-regimet - og det vil sige med hæren.

Så da befolkningen begyndte at strømme ind på Tahrir Pladsen for at kræve ændringer, støttede hverken det Muslimske Broderskab eller hæren det i særlig grad. Men da det folkelige oprør tog fart, besluttede både hæren og det Muslimske Broderskab hurtigt at tilslutte sig for at tæmme oprøret ved at søge at tage ejerskab til det. Og i anden runde af præsidentvalget imellem Morsi og en tidligere ledende figur i Mubarak-regimet, så valgte både den sekulære venstrefløj, vælgerne i centrum og hæren at stemme på Morsi, hvilket satte ham i stand til at vinde med en lille margin.

Da Morsi besluttede at gå videre og sætte en ny forfatning i kraft, som afgørende tippede magten til fordel for muslimske normer, vendte de sekulære tilbage til Tahrir Pladsen for at tage afstand fra ham. Hæren sluttede sig igen til dem for at kontrollere situationen. Og de sekulære stemmer hyldede nu den selv samme hær, som de havde taget afstand fra to år tidligere.

Den politiske situation er lige ud ad landevejen. Både det Muslimske Broderskab og det egyptiske højre (de kræfter, som længe havde støttet Mubarak) råder over tilstrækkelige stemmer til, at et rimeligt ærligt valg vil tillade den ene eller anden af de to sider at vinde. De sekulære kræfter - de mange socialistiske partier og mellemklassens centrumpartier, hvis ledende skikkelse var Mohamed el-Baradei - tæller for få til at vinde. I sidste instans må de slutte sig sammen med den ene eller den anden fløj, mens de i realiteten hverken ønsker højrefløjen eller det Muslimske Broderskab ved magten. Og de egyptiske salafister tilsluttede sig anti-Morsi koalitionen i håb om derved at styrke deres egen hånd blandt muslimske aktivister. 


\section{Omverdenen for hæren}

I resten af verden er entusiasterne for hærens aktion stærke: Israel, Saudi- Arabien, De Forenede Arabiske Emirater, Rusland, Algeriet og Marokko og sikkert også Syriens Bashar al-Assad. De utilfredse er Hamas, Ennahda i Tunesien, Tyrkiet og Qatar. Når det gælder USA (så vel som Europa), så taber de, ligegyldigt hvem der vinder. Så de er blevet irrelevante.

For Israel udgjorde Morsi en trussel, mens den egyptiske hær vil bibeholde den relative détente med Israel. For Saudi-Arabien repræsenterede Broderskabet landets største rival i den arabiske verden. For al-Assad var Broderskabet en trussel som stærk støtte af Den Frie Syriske Hær. Algeriet og Marokko arbejdede begge hårdt for at inddæmme islamistiske kræfter, så derfor hyldede de to lande Morsis fald. For Rusland garanterede Morsis fald sikkert et skifte i regionens geopolitik, og det er præcis, hvad Rusland ønsker.

For Tyrkiet (som for partiet Ennahda i Tunesien), underminerer Morsis fald sagen for 'moderate' islamiske regeringer. For Qatar svækker Morsis fald dette lands hånd $\mathrm{i}$ striden med Saudi-Arabien.

Det, som den amerikanske regering frem for alt ønsker, er stabilitet i regionen. USA var parat til om nødvendigt at samarbejde med Morsi, men havde jo længe haft de tættest mulige bånd til den egyptiske hær.
USA prøvede at balancere mellem de to, men krænkede derved begge sider lige så vel som både neokonservative og forkæmpere for menneskerettigheder i USA.

Den eneste angivelige amerikanske indflydelse på Egypten - den amerikanske hjælp, hvoraf 80 pct. går til hæren - kan ikke bruges. For det første har Saudi-Arabien og Emiraterne allerede sendt flere penge end USA har givet. For det andet har den amerikanske regering mere brug for den egyptiske hær end den anden vej rundt. Den egyptiske hær synes om at købe sit udstyr I USA, men den kan finde våben og udstyr andre steder. Den amerikanske hær har brug for den egyptiske hær på grund af overflyvningsrettigheder, efterretningsassistance, garantier for detente med Israel og mange andre ting, som der ikke eksisterer erstatning for. Så Barack Obamas rolle er reduceret til symbolske handlinger uden tænder.

Det egyptiske højre har vundet. Det egyptiske venstre har tabt (selv om det ikke anerkender den virkelighed) og det Muslimske Broderskab vil gå under jorden, hvorfra det meget vel kan dukke styrket op igen.

\section{Immanuel Wallerstein er seniorforsker} ved Yale University og forfatter til 'The Decline of American Power: The U.S. in a Chaotic World' (New Press).

Oversat fra engelsk af Vibeke Sperling. 